\title{
ARTICLE
}

DOI: $10.1057 /$ s41599-018-0177-6

\section{Trump, celebrity and the merchant imaginary}

\author{
Barry King (10 ${ }^{1}$
}

\begin{abstract}
This article explores the social ontological basis of Trumpism as a form of populism, historically defined as government by personal rule. For many commentators, the key feature of Trump's presidency is its fundamental irrationality. The President has variously described as 'dumb', 'greedy', 'psychotic', a 'narcissist' in the grandiose mode, and an 'egotist' unfit for public office. This article does not aim to dissent from these kinds of conclusions but suggests that they partake more of the statement of effects or consequences rather than causes. Indeed, if they are considered as causes they lead to confusion, a kind of 'attentiondeficit disorder' (which, ironically, some accuse the tweeting President of being a sufferer). Rather this paper suggests that a more systematic examination of the President's persona reveals it as emerging from a conflation of the discourse of the American family and a merchant imaginary.
\end{abstract}

\footnotetext{
${ }^{1}$ Auckland University of Technology, Auckland, New Zealand. Correspondence and requests for materials should be addressed to B.K. (email: barry.king@aut.ac.nz)
} 


\section{Introduction}

- he confirmation of Trump as President has created a veritable tsunami of speculation on his "real" personality as revealed in the gaps between his behaviour in office and how he presents himself through social media. Accepting that any candidate for the Presidency must have a high degree of egotism, there is general agreement, even amongst professional and eminent psychiatrists and psychologists, that Trump is mentally unstable and exhibits the symptoms of narcissistic personality disorder (Lee, 2017). Indeed, for one observer, who claims not to be acting on hindsight, Trump's conduct as a president will be an extension of his personality profile-a putatively scientific endorsement of Heraclitus' dictum that character is fate:

As a narcissist, he will only work on a superficial level and plan on hiring minions to handle details. Since he is not dealing with his own business and his own money, he will not vet personnel as thoroughly as he should. The people he chooses will be a combination of other narcissists and wellconnected yes-men.... There will be no clear voice or unity from his administration, cabinet or White House (Dr Decker, 2017) ${ }^{1}$.

Trump's tendency to confabulation has become an object of derision, not to say alarm, given the powers of the Presidency to influence national and international politics. ${ }^{2}$ One view is that Trump's penchant for self-contradiction is evidence of his stupidity. ${ }^{3}$ His reply is already on record: life's losers always bolster their flabby self-esteem by denigrating achievers (Trump, 1987, p. 59). But if he is not as clever as he thinks he is, he is not stupid. He has long believed-like Barnum and Goebbels before him-in the Big Lie, that 'little' people are mesmerized by exaggeration or as he terms it, 'truthful hyperbole' (Trump, 1987, p. 58). Others defending his chutzpah have argued that, like Walt Whitman, Trump has a grandiose personality and is therefore bound to contradict himself. Whatever his flaws, which he would be the very last to admit, he impresses his colleagues and competitors as a hyperbolic personage. One strikingly sycophantic alt-righter refers to Trump as 'the Tea Party on steroids, a modern embodiment of Sir William Wallace, who will turn Washington upside, end the gravy train and break the old boys' network'.

With its ever-unfolding contradictions and rhetorical shifts, the Trump Presidency poses the eternal question of the nature of leadership: is the leader's behavior a consequence of his or her personal qualities, or of the organizational context in which s/he operates? (Kelly, 2014) ${ }^{5}$ This query leads naturally, given a media emphasis on celebrity, to a more direct question about authenticity: is his Presidential persona rooted in his personal identity, is it a carefully constructed performance, or, in some measure, both? Trump asserts that his business success is the proof of his authenticity. Yet his public persona, parlayed live, in print or online, presents a mass of contradictions and poses problems of interpretation. Rather than having the key quality of authoritarian discourse-a fixed and ossified set of meanings-Trump's discourse exhibits a set of shifts between the authoritative and personal register, particularly through self-disclosure and the tactics of direct address associated with para-social impression management. He also propounds a transactional view of the self, minus the humanistic values of transactional analysis (Berne, 1961). For Trump, a transaction is a relationship where one's ego wins over another's. As has been argued, the emergence of Trumpism as political practice marks a deepening compaction of politics and celebrity, one that favours the hegemony of the latter. Hitherto politicians have sought to exploit the tropes and images of celebrity, the Trump Presidency marks the point where the President is a celebrity. (Street, 2018) Even Ronald Reagan, as former actor, did not present himself as a celebrity in such an untrammeled and anti-bureaucratic form. The sociological and semiotic parameters of this shift and its connection to populism is what this article explores.

\section{An empty signifier?}

At first sight, Trump's shape-shifter, 'protean' persona seems to typify an empty signifier, which Laclau defined as the key feature of populist discourse. The empty signifier is a semantic placeholder, positioned as a universal, which subsumes a congeries of disparate political interests and demands into a chain of equivalence. Empty signifiers are produced through the conflation of a set of structural oppositions; classically, the countryside versus the City or the underdog versus the powerful. It is plausible to regard Trump's rhetoric as populist in Laclau's sense because of its enunciation of core paradigmatic opposition; for example, the People versus the Federal State-'Drain the Swamp'. This opposition forms an 'equivalential' chain uniting an otherwise disparate range of popular movements-White Supremacy, Christian fundamentalism, Patriarchy, patriotism (Make America Great Again) and neoliberalism-which all have their own specific demands and ethical priorities. In Laclau's account, an 'equivalential' chain can only be integrative and hegemonic by virtue of its abstraction from the specificity of any particular movement, and it is the deployment of "empty signifiers" that achieves this. Nonetheless an 'equivalential' chain and the frontier it sustains have the potential to collapse, because of contradictions between the political forces they mobilize. To take an obvious and pertinent example, the balance in Trump's rhetoric between patriotism and the neoliberal insistence on a free market is deeply problematic in a global marketplace.

As the balance of power between the forces held in check by the equivalential chain shifts, the empty signifier converts to a floating signifier. This then in turn, through a process of struggle, leads to a new empty signifier and the formation of a new frontier that balances a changed set of social and political interests and new forms of affective investment. (Laclau, 2005a, pp. 99, 110-111, 148-149).

A key difficulty with Laclau's concept of populism centers on the concept of an empty signifier. Some content, howsoever minimal or maximal, is a pre-requisite for the formation of a representation with the capacity to recognize or misrecognize a socio-political context (Kaplan, 2012). To put this phenomenologically, being a supporter is based, however mistakenly, on a set of motives that would not be compelling if perceived as empty. This is especially the case where images are an important, if not primary, means of representation as they are in American politics. ${ }^{6}$ Moreover, Laclau's examples of frontier formation (e.g., worker's struggle) are, if ambiguous, historically full and not 'empty'. (See Laclau, 2005a, p. 79 and 2005b, pp. 36-37, 45.) The examples that Laclau provides of empty signifiers are problematic. For example, he compares the linguistic abstraction involved in forming an empty signifier to gold as a universal measure of value - an evident reference to Marx's theory of the commodity, which he otherwise considers surpassed (Laclau, 2005a, p. 93). But gold is a poor example because its substance as a signifier is of critical importance to the metabolism of capitalist exchange. In order for money to function as a universal equivalent it must meet substantial conditions-such as not being Fool's gold, or in too small a quantity as a percentage of the face value of paper notes in circulation.

Elsewhere Laclau refers to Coca-Cola as a pure signifier. Thus, we have empty, floating and 'pure' signifiers. But again a 'pure' signifier must possess the quality that sustains a claim to represent: Coke, not Pepsi, is the essence of Americanism, and its 
'purity' rests on its substantial qualities. ${ }^{7}$ Another 'pure' signifier is the name of the populist leader, which Laclau treats as the highest articulation of 'emptiness', perhaps because the qualities of the leader are fabricated (Panizza, 2005, p. 37). But, as Laclau's own examples reveal, e.g., Peronism, populist movements are finally consolidated by their association with a very specific substance-the charismatic qualities of a leader as indexed by a name. ${ }^{8}$ Moreover, Laclau's collaborator, Chantal Mouffe, has argued for an agonistic conception of politics based on respectful adversaries as distinct from an antagonistic (read class-based) conception with its friend/ enemy frontier. But whatever else it implies, agonism does not imply empty signifiers, but a liberal acceptance of difference. (Mouffe, 2009) ${ }^{9}$. Far from being an empty signifier, Trump is, pace Laclau, a replete, if anachronist signifier that is, I shall argue, positioned imaginatively and economically outside of contemporary capitalism.

A key feature of Trump's discursive practice is the production of contradictory and illogical connections (Hall et al., 2016). This is most apparent when the President issues a barrage of tweets that contradicts or at least problematizes official White House pronouncements, driving a rift between the charisma of Office and his persona. Under these circumstances-compounded by leaks-instead of a single and unifying 'frontier' there appear to be multiple 'frontiers' circulating, some internal and some external, that recompose the lines of opposition between the President on the one hand and on the other, a disparate cast of White House staff, the Republican Party, and an ever-emergent list of enemies including the media and foreign governments. Rather than an ideological mode of unification under a common opposition, Trump, by intention or default, flaunts a procession of frontiers based on a rapidly shifting set of oppositions between friends and enemies, ever raising up the contradictions implicit in particular struggles. What emerges is not unification as an ideological mode but divide-and-rule on steroids (Thompson, 1990, p. $60)$.

In Laclau's account the political logic of populism is a process of translation from metonymy to metaphor-it is metaphor that 'quilts' and holds disparate parts of the movement together. But Trump is also a celebrity and in that realm, the construction of an equivalential chain is driven by the need to consolidate a particular instance as the unique signifier possessing the whole. What is at stake here is a relationship of possession by synecdoche. Synecdoche is uni-directional entailment that pragmatically rejects the subordination of the part to whole in favour of treating a part as a replete monad that engrosses the whole, in which it is conceptually and materially embedded (Bredin, 1984; Moore, 2003). This is eminently the realm of Trump.

But in contrast to the usual practice of projecting a consistent persona, with safeguards against discrepant behavior, Trump's rhetorical signature refuses to posit a stable core, rejecting factual evidence and the integrity of the media (fake news), disdaining constitutionally-mandated institutions, dodging accountability, and making a show of inconsistency on record through ad-hoc remarks and tweets. The supreme value behind this strategy is the serviceable truth, the one that wins the argument:

Trump told Clinton in a debate....that if he were president, 'you'd be in jail.' But after the election, when attendees at a trump rally chanted 'lock her up', Trump shrugged it off. 'That plays great before the election-now we don't care, right?' (Jamieson and Taussig, 2017, p.16).

This kind of re-voicing is consistent with Trump's view that life is a competitive sport where one maligns one rivals in order to win but in winning becomes gracious. ${ }^{10}$ The election was the biggest deal of his life, but he won and it's time to move on. What is true is what works in the situation. Dealing is about seizing the opportunity, which by definition is a one-off event that when successfully concluded can be forgotten.

In sum, Trump's populism seems the opposite of Laclau's theory of populism. What is in train is an overly replete and quasi-authoritarian welding of signifieds to a singular signifierTrump's persona-that, far from empty, exhibits a grandiose narcissistic fullness. A better conceptualization of Trumpism as a populist ideology is to see it less as a transcendent signifier than as a core meaning that sets in circulation an ensemble of peripheral positions that need to be contested if the core is to prevail (Freeden, 2006). Trumpism, like the shift towards Right Wing politics in Europe and elsewhere, is an exclusionary form of populism, excluding 'outsiders' and those within the USA who are not adjudged to have the qualities necessary for inclusion within the Republic (Betz, 2001). The core 'licenses' or warrants certain peripheral relationships and not others. Before elaborating the structural features of the core, it is necessary to consider Trumpism as a biographical account.

\section{The legend of the deal-maker}

I don't do it for the money, I've got enough, much more than I'll ever need. I do it to do it. Deals are my art form (Trump, 1987, p. $1)$.

Any text or body of texts is governed by a recurrent pattern of meaning-making (a register) that regulates the relationship of the text to its environment, even as it reveals that environment in a particular form. A register, in short, governs the transitivity of a text, its mode of connecting to the world to which it refers. A body of texts that share common linguistic features can be said to operate within the same register. The components of a register are:

Field: The representation of specific kinds of actors, subjects and themes, with ascribed purposes, intentions and causes.

Tenor: The kinds of interactions and forms of participation between participants in the speech (or equivalent) situation that are understood as given; the definition of the participants' rights and obligations, explicit or implicit.

Mode: The channels through which the materials of expression function-spoken, written, scripted, unscripted, live or recorded -and the genre of the materials of expression: narrative, exposition, argument, phatic, didactic, hortatory and so on (Halliday and Hasan, 2014, pp. 21-30, 294). ${ }^{11}$

For my purposes the key dimension is field. This means taking Trump at his word (or the words of his approved ghost writers). ${ }^{12}$. Thereafter I will explore the relational tenor as the background intersection of familism and merchant epistemology. This background, implicit in the surface discourse, marks the unquestioned and, if questioned, the non-negotiable core of Trumpism as a species of populism.

In The Art of the Deal, the ghost-written Bible story of his success, Trump consolidates his persona as an astute dealmaker and real estate speculator. Rather discounting himself as a member of the 'lucky sperm club', he attributes his success to hard work-a trait he inherited from his picaresque grandfather, Friedrich Trump, and his German Drumpf ancestors (Johnson, 2016; Trump, 1987, p. 227).

Of more immediate impact on the formation of his personality were the lessons he learned from his parents. Trump observes that he took from his father business competence, efficiency and a deep schooling in the promotional wiles of real estate speculation; from his mother, a taste for splendor and magnificence, or 'class', as a baroque demonstration of affluence. True his family did not just provide the moral fiber and taste to succeed. His father, Fred, bankrolled his ventures, provided leverage through political connections, networks and cronyism, and left his son $\$ 40$ million 
when he died in 1999 (Trump, 1987, p. 105; see also Blair, 2005; pp. 16, 22-24, 32, Porter and Prince, 2016; p. 360). But this financial contribution is not the stuff of character which the son forged out of his own actions. So, for example, he idolized his father Fred, as a true Horatio Alger figure, and yet found the family business in rent-controlled real estate development lacking finesse and lacking in loftier dreams (Trump, 1987, p. 79). He associates welfare with sleaze, yet to finance deals he has relied on tax breaks and, later in his career, on the threat of declaring himself bankrupt under chapter 11 (four times) to force banks to extend loans. As a Presbyterian, he espouses Christian values yet although 'a very nice person', is ruthless in the pursuit of economic advantage (Trump, 1987, p. 108); in his view, the worst of economic times for others creates the opportunity for him to make the best deals (Trump, 1987, pp. 102, 200); a good reputation is all, but from a bottom line perspective, bad publicity can be just as good (Trump, 1987, p. 176); he trusts no-one but is prepared to employ crooks so long as they deliver profits (Trump, 1987 , p. 86). He feels sympathy for rent-controlled tenants and is not racist, yet the Justice Department found he discriminated against black tenants and welfare recipients in 1973, and he was later accused of harassing sitting tenants in properties he acquired on the cheap. Such contextual factors are excluded from his account of his personal rise to fame, as are significant other external factors that enabled his success.

Among the many 'enablers' one might cite mobster connections in Atlantic City, the fiscal crisis of New York City that enabled Trump to secure preferential loans and tax advantages for property development, the timidity of bankers, and media attention. The reality television show, The Apprentice is especially significant because it enabled Trump to burnish his public image which, from the perspective of New York High Society, marked him out as a vulgar upstart and a "loser" in a status competition; the media, particularly Rupert Murdoch's New York Post as the court recorder of Manhattan High Society, played a significant role in this process, along with the New York Observer (Wolff, 2018, pp. 73-76).

In sum, for all he presents himself as the heroic independent entrepreneur, his career has relied on exploiting legal loopholes, tax breaks and substantial corporate and banking support. He depicts himself as a self-starter from a modest background, and yet builds his own career on the resources of the Trump Organization and conditions of considerable risk and corporate bluff. Donald Trump in the 1990s could be seen as running a property asset-based Ponzi scheme which narrowly missed collapse (Capehart, 2015). ${ }^{13}$

\section{Building the Trump persona}

In Trump's efforts to overcome his déclassé standing in New York High society, The Apprentice plays a key role, consistent with the genre of Reality Television overall, confirming his persona as a hero of neoliberalism (Ouellette, 2016).

As established by the opening sequences of The Apprentice, with a Trump voice-over and power images of the Manhattan skyline, the opulent settings of Trump Tower and other Trump properties, New York is the toughest city in the world in which to do business. Thus Trump, depicted as a fabulously successful plutocrat, is uniquely qualified to judge the entrepreneurial stamina of his carefully selected and passionately sycophantic contestants.

In the series, Trump is represented as the living epitome of New York, whose qualities of toughness, competitiveness and, brash opportunism he has made his own. So that if the show is a celebration of neoliberal meritocracy-success as market performance-the ultimate effect is to construct an apotheosis, a nouveau-riche family for whom winning is everything and whose members, by a halo effect, inherit the qualities of the father.

Commercially, The Apprentice marked a significant transformation because it enabled Trump to leave behind his propertydeveloper career and operate as a transferrable brand. ${ }^{14}$ His postelection performance as President with all its contradictory claims, braggadocio and flat-out sexism can certainly be seen as evidence of a narcissistic personality. But being outrageous is also part of an approach to public relations and self-promotion that he has practiced for decades.

'He built his career by being media-friendly. The last 18 months have been something of an aberration in his approach', said NewsMax CEO Chris Ruddy, a Trump confidant who has known the president for 20 years. 'I've always said he's just creating a negotiating position by calling the press the enemy of the people. I don't think he believes that deep down' (Schreckinger and Gold, 2017)

The speculation that Trump does not believe what he publicly proclaims suggests another habitual feature of his discursive practice-self-disclosure as a means of drawing the reader or listener into closer relationship with his 'authentic' self. This feature is apparent throughout The Art of the Deal and his comeback book Trump: The Art of the Comeback (1997). It also plays an important role in his election campaign for President as his pre-electoral pièce de résistance, Crippled America: How To Make America Great Again (2015) makes clear:

Some readers may be wondering why the picture we used on the cover of the book is so angry and so mean looking. I had some beautiful pictures taken in which I had a big smile on my face. I looked happy, I looked content, I looked like a very nice person.... But I decided it wasn't appropriate. In this book we're talking about Crippled America. Unfortunately, there's very little that's nice about it (Trump, 2015, p. ix).

Or:

For years I had thought about-but resisted-running for the presidency. Friends, colleagues, and customers encouraged me to do something. 'I thought, I'm not a politician, and I have a huge, successful business to run'.

But then I realized I couldn't stand what I was seeing. I couldn't believe the hypocrisy and inaction of Washington 'insiders' who wanted to keep the gravy train flowing in their direction, while outside the Beltway, Americans were suffering and they were rightfully angry about the lack of leadership and creativity (Trump, 2015, p. 163).

Again:

I learned a long time ago that if you're not afraid to be outspoken, the media will write about you or beg you to come on their shows. If you do things a little differently, if you say outrageous things and fight back, they love you. So sometimes I make outrageous comments and give them what they want-viewers and readers-in order to make a point. I am a businessman with a brand to sell. When was the last time you saw a sign hanging outside a pizzeria claiming 'The fourth best pizza in the world'?! But now I am using those talents, honed through years of tremendous success, to inspire people to think that our country can get better and be great again and that we can turn things around (Trump, 2015, p. 11).

The moments of reflexive commentary and self-disclosure contained in these statements are clearly aimed at persuading the 
American general public to become part of the specific constituency of Trump supporters, designed to drawn out the trust of readers and viewers who otherwise might be seen as the target of manipulation. Trump intimates he may exaggerate and pose but that is in the cause of those who have been exploited by Washington hacks and political opportunists. At the same time, he does not neglect to reveal how successful he is as an entrepreneur and how nice he is as a person, although hard times (caused by others) demand that as a patriot he takes a hard line and assume a tough appearance. His authority to speak for core American values and opportunities is demonstrated by his business success in the greatest country on earth, the USA, where winners are rewarded according to the measure of their hard work and success. Anyone doubting his ability to do great things can apply a simple empirical test:

You can believe what I say, because to see what I have accomplished, all you need to do is take a nice walk through the greatest cities in the world-and look up. Look up and you'll see the Trump buildings rising skyward (Trump, 2015, p. 165).

For stubborn sceptics there is a friendly caution:

Don't bet against what I am saying-I understand odds very well-because I've always tackled the hardest challenges and come out on top. My name has become one of the greatest brands in the world. I know how to win (Trump, 2015, p. 162).

In these and other statements Trump clearly seeks to represent himself as the consummate outsider, the charismatic leader whose personal qualities alone make him fit to overturn an ossified and corrupt bureaucratic system. The one who is prepared to say what lesser men smother with silence and acquiescence. As the flyleaf proclaims:

This book is my blueprint for how to Make America Great Again. It's not hard. We just need someone with the courage to say what needs to be said. We won't find that in Washington, DC.

The figure of the ordinary man of the people who has extraordinary talents is a recurrent motif in Trump's self-presentation, which aligns with core features of populism: (a) the identification of two antagonistic units of analysis, the people versus the elite; (b) 'the people,' a weakly differentiated and ill-defined category, celebrated as a source of positive values which the leader shares; (c) popular sovereignty as an overarching political imperative. The world-in this case Crippled America-can be a better place if the people are allowed to speak and Donald Trump is their megaphone. (Mudde and Kaltwasser, 2013, p. 151).

Populist discourse invariably invokes a golden age, which in this case is saturated with the values of white supremacy. But Trump is not an overt racist, a charge he would deny; rather, he offers himself as the competitively valorized brand of the White Republic which is intrinsically racist. Formally, the ideological mechanism underlying Trumpism rests on an evacuation by reduction of contemporary class conditions, a prestidigitation of class. Evoking an ahistorical state of nature (as argued by Lefort, 1986 , p. 201), this evocation is then condensed into the persona of Trump as a media-created brand. Trump's self-projection has affinities with celebrities, whose raison d'être is to be personalized examples or prototypes that exhaust a type (King, 1992). Given the super-ordination of a concrete particular over a whole category - in this case the office of the President - it is not surprising that Trump as a celebrity can act as a personal brand for a plenitude of disparate services and commodities.

\section{His master's double-voicing}

As a discursive practice, Trumpism rests on a variant of doublevoiced discourse that is marked by a hidden polemical intent.

In a hidden polemic, the author's discourse is directed toward its own referential object as is any other discourse, but at the same time every statement about the object is constructed in such a way that, apart from its referential meaning, a polemical blow is struck at the other's discourse on the same theme, at the other's statement about the same object (Bakhtin, 1994/1963, p. 108).

Trump obsessively positions his self against Others. In press and political briefings, and par excellence in his tweets, this polemic stance is manifested in name-calling against opponentsJeb Bush, the previous administration aka Barack Obama, Mitt Romney, Megyn Kelly, Hillary Clinton, John McCain, Kim Jongun and so on (Lee and Quealy, 2017).

Trump's discursive practice involves double-voicing as a serial practice, a mercurial shifting through different modes of media, sites of self-presentation and audiences, committing gaffes in the process. If the new media ecology provides opportunities for reaching out to diverse constituencies, it also manifests contradictions through assembling remarks targeted to different constituencies in a common attention space. Hence the contradictory juxtaposition, for example, of his flattering remarks to the Chinese leadership and his declaration of a 'get tough on China' policy through the imposition of tariffs. Such contradictory double-voicings are in turn multiplied and redoubled in the Public screen by journalists, activists and social media users adding their own gloss on the President's behavior. (DeLuca and Peeples, 2002) The President's penchant for tweeting insults and affectively charged language when set against the White House Press Office practices merely compound the impression of a low level of cognitive integrity conveyed emotion-laded simple terms such as 'bad', 'dumb', 'great', 'nice', which beg a series of questions _-'bad' 'nice' for whom? (Shafer, 2015; Crockett, 2016).

Trump's double-voicing only seems inconsistent if one fails to make a distinction between what is for general consumption and what is a coded message or an aside to a concrete sub-group or community-his base. Indeed, his loyal followers are disposed to distinguish between what he says for public consumption and what he authentically means. (Hahl et al., 2018)

The subjects of Trump's exclusionary populism are a convocation of White Americans who share the perception that their national heritage is being stolen by the 'over-population' of nonwhites, multiculturalism, affirmative action, capital flight and the influx of 'cheap' immigrant labour. The Golden Age to which Trump promises to restore America is the post-second World War period of increasing prosperity, high employment and high moral purpose for the White majority. Yet the decades of the 1950's and 1960's where Trump spent his formative years as a child and young adult were only a partially inclusive reality even for Whites, and one that began to unravel from the late sixties onwards (Giroux, 2002).

In a manner reminiscent of Silvio Berlusconi, Trump presents himself as a self-made man of the people whose charismatic qualities - his extraordinary talents and intelligence - have been demonstrated by his success as a businessman. (McDonnell, 2016, p. 5.) ${ }^{15}$ For all intents and purposes, Trump speaks from outside American civic and political culture. $\mathrm{He}$ is a President whose ideology has never been explicitly or coherently stated (Enten, 2016). Discursively removed from the real conditions of his class existence as a capitalist insider, Trump projects himself as an outsider drawing his followers into a condition outside history wherein they identify as a series-a herd of disparate groups that 
share a common imaginary focus but not a common agenda and set of values (Sartre, 1991, pp. 256-269)

In reality, the alignment of Trump supporters to the White republic is complex and even contradictory. Different cultural groups and socio-economic classes that make up the White Republic experience contemporary conditions differently. Indeed, the same identifiable category, say blue-collar workers, may experience outsourced production as providing the immediate benefit of cheap goods-at least as long as other workers, not them, are losing jobs. Arlie Hochschild, in her study of Tea Party adherents, notes the underlying persistence of a deep story behind the attitudes of her respondents (Hochschild, 2016, 2017). The deep story evokes the existence of a queue lined up to enter a 'shining city on a hill'-a heavenly place where there will be an ultimate recognition of their inner worth and a just reward for their as-yet-unrecognized sacrifices. Yet if her respondents have worked hard, paid their taxes and borne up under ill-healthironically caused by the industries they wish to defend against environmental regulation-their place in the middle of the queue (aka the class structure) - is being threatened by queue-jumping. The queue-jumpers are the undeserving outsiders-blacks, browns, immigrants, welfare recipients, single parents and other assorted hangers-on-that threaten the values of the White Republic (Jacobson, 2017; Roediger, 1999; Mertz, 2017). Worse still, the then president, Barack Obama, is acting like a black night-club bouncer, authorizing the cutting-in of the undeserving.

In the molecular travails of their daily lives, these Tea Party adherents operate a moral economy, a theodicy of the deal-I suffer this to get that. This moral calculus rests on the soteriological fantasy of the Rapture, when good Christian folk will join the company of heaven, leaving the unbelievers and sinners behind on an Earth that has become is a living hell. But as striking as the metaphor of the Rapture is an explanation of how Trump supporters manage the cognitive dissonance created by Trump's behavior. It has a worrying and potentially fallible outcome of casting him as a savior. ${ }^{16}$ For his purpose is not to redeem anyone, but to set the rules of the game so that the worthy may redeem themselves by their own entrepreneurial effort.

As Thomas Frank observed, in the nineties market populism had become the dominant political framework in which markets were no longer mechanisms of exchange but, if left to work untrammeled, attain the highest degree of popular consensus and are thus the essential expression of democracy (Frank, 2001, pp. xiv-xv, 15).

\section{Gamester, trickster, con-man?}

Significantly, during his highly successful 'star turn' on The Apprentice, Trump enjoyed high ratings with Afro-American and Latino audiences and in some measure spoke to their aspirations. Preparing for his Presidential run, Trump began the process of aligning his appeal with White republican opinion-starting with his 'birther' attacks on Barack Obama, followed with negative comments about Mexicans and Hispanics (Green, 2017, p. 101). A key linguistic feature of this switch to racism concerns the degree of specificity given to the term 'the people' that begins to function as an affective signifier rather than as a specific address to an identifiable social group or constituency. Trump does not say that by the term people he means white folks, but folks, likely to be mostly white, who are passionate patriots like himself (Chilton, 2017).

Where Trump assumes the (ghost-writer-enabled) burden of encouraging people to accept his vision, the Others are left vague, defined negatively only by contrast to himself as a nice person, a great success and so on. For some, such flattering self-references may 'protest' too much. But they are designed to cultivate trust and belief, portraying Trump as a charismatic leader who speaks for the people. Yet portraying himself as an outsider who is prepared to take on the dark forces that are 'crippling' America, Trump does not place himself too far outside a fundamental belief in American capitalism. He is not an absolute outsider in the manner of a charismatic prophet aiming to destroy the prevailing order. Rather he celebrates his elite connections and business triumphs as an affirmation of his competence. He is not merely positioned by his great wealth as out of touch with the life experiences of the majority of Americans today, but he was never in touch with everyday experience in the heyday of the White Republic, which he implicitly evokes as a golden age. At the level of his personality, the sense of entitlement he exhibits stems from the fact that he grew up, built a career and made his fortune within the protected environment of the family firm. For most of his professional life before his ascent to the office of President, Trump managed his own public relations as the head of the Trump Organization as a private business.

This economic base, sheltered from the challenges of competing with others in a corporate setting, has nurtured his sense of entitlement and the tendency to see, or at least claim, excellence in all his undertakings. In his book The Culture of Narcissism, Christopher Lasch reports on the emergence of a new kind of narcissistic corporate leader, the gamesman. This corporate type is engaged in service-relationship development rather than material products and places a greater emphasis on running his team (with empire-building and wealth-making as desirable byproducts) and securing victories over rivals. The gamesman wants to be known as a winner and fears most of all being seen as a loser (Lasch, 1991, pp. 44-45). This configuration, with a notable exception, characterizes the character set of Donald Trump (D'Antonio, 2016, p. 70-71). The exception is that Trump has not - until his assumption of the Presidency-had to work within a bureaucratic corporate environment, so that his narcissistic and gaming tendencies have been indulged to the full. Being used to making his own decisions, hiring people who will carry out his wishes and getting his own way in dealings with business associates and legal authorities has meant that he sees himself as a player focused exclusively on his own game, with the key problem of knowing what he wants and the best way how to get it. To a large extent, The Art of the Deal can be read as the art of getting one's way with others. The single-minded pursuit of self-interest in a low-accountability context has meant in the past walking a thin line between legal and illegal practices-charges of discrimination against Afro-Americans, employment of undocumented immigrant employees, and the impending indictment under the RICO act (settled out of court) for fraudulent practices associated with Trump University are just some examples of behavior that could lead to his impeachment. (Lichtman, 2017).

Viewing Trump's chaotic and ill-coordinated public performances suggests a deeper cultural resonance than that evoked by Lasch's corporate gamester. Rather, he is a modern-day Trickster, the figure who creates and destroys, affirms and denies commonly held values, dupes others and in so doing dupes himself.

Yet in contemporary America, according to Lewis Hyde, the most common American type is not the Trickster but the Confidence man, the one who deceives within and not against the existing order. His media performances challenge received political practice and standards of accountability and, as painful as it maybe, bring into being new ways of knowing and perceiving. In Hyde's account, the trickster function has been devolved or is parceled out to the artist (Hyde, 1998, p. 13).

In some respects, Trump seems a prime example of the confidence man (Hearn, 2017). But he seems to believe his own confabulations and view them as aesthetic expressions. Is he not on his own recognizance, an artist of the deal and begetter of 
buildings whose luxury and opulence are said to beggar the imagination? Each of his deals is a stand-alone work of art and an instance of the highly focused exercise of his creativity.

Unlike the trickster Trump does not mock or criticize are certain institutions which take on the patina of eternal truths, beyond the exigencies of the moment of the deal. Supreme amongst them is the free market as the arbiter and mediator of social inequality and the engine of progress. Thus behind his rhetoric of popular empowerment and creative destruction operates an elite agenda-tax reduction, market deregulation, removal of restrictions on environmental exploitation, privatization of health insurance, and so forth. Such policies-whatever their likelihood of becoming law-are blatant expressions of ruling-class interest and have the potential to bring economic hardship to his supporters, let alone the working poor, welfare dependents and the racial and ethnic groups excluded from the White Republic.

This winner class-based agenda does not lack an existential bite in popular experience (Choma and Hanoch, 2017). First, it taps into white working and middle-class racism as a means of forming an in-group of whiteness (Coates, 2017). But within this fractured and economically divided imagined community, it is necessary to construct a communality of experience. Competing and striking deals is an everyday experience in capitalist societies, whether in terms of work, family life, romantic and sexual relations, or the multitude of simple exchanges such as purchases, barter and gifting:

... a chain of significance runs from our minor daily encounters with competition, whether at work or at leisure, and the great competitions for political office and economic might that frame liberal society. It runs also from our personal experiences of distinctions between private and public dimensions of our own lives that we want to preserve, and great public debates about the proper limits of the state's claims on the individual, and vice versa (Hearn, 2011).

\section{Merchant truths held most dear}

It would be homage to Trump's self-aggrandizement not to recognize that the way he frames his public persona is in accord with established cultural practices. The framing of his persona as a successful entrepreneur follows contemporary corporate promotional practices that emphasize strengths and downplay failings (Cho et al., 2010; Wernick, 1991). Again, Trump's approach to self-promotion is an expression, with its particular idiosyncrasies, of the long-phased process of staging the Office of Presidency as a populist spectacle (Combs and Nimmo, 1993, pp. 118-119). Finally, his approach to self-publicity is at one with the practices of celebrity culture, where 'charisma' is reductively rendered as a quality of the individual rather than an organizational or institutional product (Turner, 2003). This factor is most apparent when Trump speaks of 'building' his signature skyscrapers when he means, of course, he paid to have them built or is now paid for permitting others to put his brand on their buildings. Such an intense personal framing constitutes the zerodegree level of personification that others have identified as a narcissistic. Recalling the distinction between a totem as representing some collective entity and a fetish as a self-referencing particular, Trump constructs his persona as a fetish.

The factor of personal narcissism acknowledged, part of the explanation for this fetishism stems from his background in family capitalism. Family capitalism is marked by an ambiguous view of the market. On the one hand, it aims to avoid as far as possible external sources of capital such as the issue of stocks and shares for financing business ventures. The preferred source of funding is from family resources or from personal loans from merchant banks (Jones and Rose, 1993; Lisle-Williams, 1984). On the other hand, the 'free' market remains the absolute standard of performance-both for the individual and for the nation. It goes without saying that Trump, father and son, needed to succeed, however cushioned from market pressures, in their property dealings. To that extent, the aura of success is justified. But the fact of their success, where others unaccounted have failed, also vindicates a particular view of the world that rests on a mercantile epistemology, whose origins reference an earlier phase of capitalist development. This way of understanding the conduct of politics sees business people, especially traders experienced in commercial bargaining, as the best custodians of the national interest, provided the market was permitted to apply the supreme test of objectivity-the successful deal (Deringer, 2017). To this extent Trump's career provides a metaphor for the action of the market.

The second aspect stems from the fact that over his career, Trump's operations have become increasingly divorced from the material production of value, relying on the power of money to beget money. The circuit in which money begets money (M-M) represents the highest form of capital fetishism (Marx, 1981, pp. 744-745, 516, 525-542 Harvey, 1982, pp. 266-267; Boer, 2011). In accord with his lifelong occupancy of the realm of fictitious capital, where money generates money without engaging with the realm of material production, Trump has crafted the persona of the exemplary deal-maker with a Midas touch. As one admirer put it:

When Donald Trump built Trump Tower, he created a market for ultra-luxury real estate in Manhattan that had not previously existed. He had the foresight to believe that he could turn a worn-out department store into one of the most prestigious addresses in the world. Using one of his favourite real estate investing strategies, Trump combined an irreplaceable location with innovation and the end result was a portfolio of properties worth nearly one billion dollars (Thomas, 2016, p. 19).

\section{All in or out of the family}

What is Trumpism? It is a narcissistic variant of Bonapartismwhich Marx characterized as a personal form of rule that emerges in a situation of class stalemate, with the capitalist class divided and the working class (along with a shrinking middle class) lacking the institutions that can unite a variety of political struggles articulated around factors of race, class, gender, ethnicity and sexual orientation (Marx, 1994; Streeck, 2017). Trump seeks to reduce the conduct of the White House to a family business, promoting his family and friends to key government positions and expecting respect and loyalty consonant with a lifelong experience of mixing affective ties with commercial activities (Wolff, 2018, pp. 83-85). When members of his familycentered network displease him he dumps them, disregarding continuity and the service they have already provided as well as the social perception of chaos.

So Trumpism is not just a response to a social order in disarray; it is also a defense of the fundamental unit of sociation favoured by Conservatives, the Standard North American Family (SNAF). SNAF, more of an ideal than reality, identifies the good society with the White, heteronormative nuclear family of father, mother and children obedient to the 'natural' order of patriarchy (Collins, 1998; Smith, 1993). In Trump's version, which if consistent with Christian fundamentalism, is not devout, SNAF celebration is linked to a reductive and privative version of 
patriotism: proving America is great because it supports the pursuit of private advantage and the enrichment of the self, kith and kin and friends. Nationhood is thereby cast in an exclusionary form. This is because the ultimate benchmark of success, the market, does not merely express the popular will, but also objectively determines who represents the highest and most exemplary expression of this will. In Trump's variant of populism, it is not just the Others outside the White Republic that are excluded, but those whose racially warranted belonging as Whites is not matched by their entrepreneurial achievements or by the adoption of White phenotypical behavior (Kunst et al., 2018. They are 'losers'.

In Trump's vision the real America finds its ontological ground as Mar-a-Lago, his exclusive club and the 'Southern White House'. Here Winthrop's vision of a shining city on the hill has long ago morphed into the gated community of the cliques, the coteries and the families of plutocrats. With the Trump Presidency, the West Wing, as popularized in the long running television series, has succumbed to the Lifestyles of the Rich and Famous.

Received: 27 November 2017 Accepted: 27 September 2018 Published online: 30 October 2018

\section{Notes}

1 Trump's Brain: An FBI Profile of Donald Trump. Dr Decker (a pseudonym) the author of a mock FBI profile, makes strikingly precise predictions about the appointment of family and friends to the White House and public office. It is claimed that the predictions were written before Trump took office but this seems unlikely. Nor does it need any 'psychological' profiling to explain Trump's preference for nepotism and cronyism.

2 Trump's settlement of a class action case against (so-called) Trump University for $\$ 25$ million should have been enough to sink his candidacy, as Mitt Romney and Ted Cruz hoped.

3 See for example, Trumped, the wonderful world and wisdom of Donald Trump which has many quotes that affirm self-love, e.g., 'It is very hard for them to attack me because I am so good looking' (Whiticker, 2016, p. 112).

4 Wayne Allan Root 2016, Angry White Male, p. 170-171. The bad guy in Braveheart is Edward I, also known as Longshanks and The Hammer of the Scots. No surprise then that Root sees his modern equivalent as King Obama, the hammer of the middle class (p. 173). Televangelist Jerry Falwell, never to be outdone in hyperbole, has referred to Donald Trump as embodying the best qualities of Jesus Christ and Martin Luther King, Jr.

5 Kelly proposes a negative ontology of leadership using the idea of empty signifiers. As already noted I do not believe signifiers can be empty, though they may 'float'; nor by implication does Kelly, where the factors related to leadership are shown to be replete and hence in need of a complex process of integration (see p. 908).

6 Hjelmslev (1961) semiotic is the key resource. Both the plane of expression and the plane of content have a form and content. Because of his adherence to Saussurean semiology and its legacy of logocentrism, Laclau's formulations are reductive, especially but not solely in relation to visual signs. This reduction, a sort of verbocentric Occam's Razor which Laclau regards as logically robust, does not identify specific movements in particular but treats all movements as bearers of a generic political logic (On Populist Reason, p. 117).

7 Laclau is talking about the degrees of abstraction between signs and their referents. But the notion that an abstraction can ever attain emptiness is fanciful. An empty signifier is a contradiction in terms. He favours degrees of emptiness when it would be more accurate to concentrate on degrees of fullness. But then his whole attempt to escape the determination of content through an emphasis on form would be compromised.

8 Since Trump is promoting a brand, what's in a name is not 'floating' or empty, but a commercially proscribed set of qualities.

9 For a discussion of the consonance between Trump's rhetoric and the Tea Party see Goldstein (2011) passim, but especially pp. 842-845.

10 . In Trump's world, fellow members of the ruling class compete and, at a close of game, shake hands. Given his blatant misogyny, it is unlikely that Trump viewed Hillary Clinton as an honourable rival, even though she belongs to the same social class and in past times was a friend along with Bill Clinton.
11 For reasons of space, I will not focus on this dimension, not the least because there is abundant commentary on Trump's abrasive and bombastic style. Johnson (2016) refers to Trump as a world-class narcissist (p. 287).

12 Tony Schwartz has subsequently said that Trump is a very damaged and vacuous human being.

13 Porter and Prince (2016) report that Trump would have made a fortune of $\$ 13$ billion by simply investing in a Standard and Poor's Mutual fund (p360). But the armchairand-slippers life of quiet accumulation would not have assuaged Trump's desire for fame.

14 Johnson (2016) details mobster connections; see Chapter 5. Trump's brand is not always successful; for example, Trump Magazine and his Atlantic City casinos failed. 15 In this sense, Trump is a pseudo-trickster.

16 Though there is recent evidence that Trump's base is fragmenting (McCarthy, 2017).

\section{References}

Bakhtin M (1994) Double-voiced discourse in Dostoevsky. In: Morris P (Ed.) The Bakhtin reader: selected writings. Edward Arnold, London, p 102-111. (Original published 1963.)

Berne E (1961) Transactional analysis in psychotherapy: a systematic individual and social psychiatry. Grove Press, New York, NY

Betz HG (2001) Exclusionary populism in Austria, Italy, and Switzerland. Int J 56 (3):393-420

Blair G (2005) Donald Trump: master apprentice. Simon and Schuster, New York, NY, London

Boer R (2011) Kapitalfetisch: The religion of everyday life. Int Crit Thought 1 (4):416-426

Bredin H (1984) Metonymy. Poet Today 5(1):45-58

Capehart KW (2015) Hyman Minsky's interpretation of Donald Trump. J Post Keynes Econ 38(3):477-492

Chilton P (2017) 'The people' in populist discourse :using neuro-cognitive linguistics to understand political meanings. J Lang Polit 16(4):582-594

Cho CH, Roberts RW, Patten DM (2010) The language of US corporate environmental disclosure. Account, Organ Soc 35(4):431-443

Choma BL, Hanoch Y (2017) Cognitive ability and authoritarianism: understanding support for Trump and Clinton. Personal Individ Differ 106:287-291

Coates TN (2017) The first white President. The Atlantic, p. 74-87

Collins PH (1998) It's all in the family: Intersections of gender, race, and nation. Hypatia 13(3):62-82

Combs JE, Nimmo DD (1993) The new propaganda: the dictatorship of palaver in contemporary politics. Longman Publishing Group, London

Crockett Z (2016) What I learned analysing 7 months of Donald Trump's tweets. https://www.vox.com/2016/5/16/11603854/donald-trump-twitterAccessed $30 / 7 / 2017$

D'Antonio M (2016) The truth about Trump. St Martin's Press, New York, NY

Dr Decker (2017) Trump's brain: an FBI profile of Donald Trump: predicting Trump's actions and presidency. Independently Published, USA

DeLuca K, Peeples J (2002) From public sphere to public screen: democracy, activism, and the 'violence' of Seattle. Crit Stud Media Commun 19 (2):125-151

Deringer W (2017) It was their business to know: British Merchants and Mercantile Epistemology in the Eighteenth Century. Hist Political Econ 49 (2):177-206

Enten H (2016) We've never known less about an incoming President's ideology. https://fivethirtyeight.com/features/trump-ideology/ Accessed 2/8/2017

Frank T (2001) One market under God: Extreme capitalism, market populism, and the end of economic democracy. Secker and Warburg, London

Freeden M (2006) Ideology and political theory. J Political Ideol 11(1):3-22

Giroux H (2002) Neoliberalism, corporate culture, and the promise of higher education: the university as a democratic public sphere. Harv Educ Rev 72 (4):425-464

Goldstein JA (2011) The Tea Party movement and the Perils of Popular Originalism. Ariz L Rev 53:827

Green J (2017) Devil's bargain: Steve Bannon, Donald Trump, and the storming of the presidency. Penguin, New York, NY

Hall K, Goldstein DM, Ingram MB (2016) The hands of Donald Trump: entertainment, gesture, spectacle. HAU: J Ethnogr Theory 6(2):71-100

Hahl O, Kim M, Zuckerman Sivan EW (2018) The authentic appeal of the lying demagogue: proclaiming the deeper truth about political illegitimacy. Am Sociol Rev 83(1):1-33

Harvey D (1982) The limits to capital. Blackwell, Oxford

Halliday MAK, Hasan R (2014). Cohesion in english. London, Routledge

Hearn A (2017) Confidence man Soundings 66:79-89

Hearn J (2011) The strength of weak legitimacy: a cultural analysis of legitimacy in capitalist, liberal, democratic nation-states. J Political Power 4(2):199-216

Hochschild AR (2017) The ecstatic edge of politics: sociology and Donald Trump. Contemp Sociol 45(6):683-689 
Hochschild AR (2016) Strangers in their own land: anger mourning on the American right. The New Press, New York. NY

Hjelmslev L (1961) Prolegomena to a theory of language. (Trans: Whitfield FJ). University of Wisconsin Press, Madison

Hyde L (1998) Trickster makes this world: Mischief, myth, and art. Canongate Books, London

Jacobson GC (2017) The triumph of polarized partisanship: Donald Trump's improbable victory in 2016. Political Sci Q 132(1):1-34

Jamieson KH, Taussig D (2017) Disruption, demonization, deliverance, and norm destruction: the rhetorical signature of Donald J. Trump. Political Sci Q 132 (4):619-650

Johnson DC (2016) The making of Donald Trump. Melville House, Brooklyn

Jones G, Rose MB (1993) Family capitalism. Bus Hist 35(4):1-16

Kaplan M (2012) Missing Misrecognition. Culture, Theory and Critique 53(3):1-12

Kelly S (2014) Towards a negative ontology of leadership. Human Relat 67 (8):905-922

King B (1992) Stardom and symbolic degeneracy: television and the transformation of the stars as public symbols. Semiotica $92(1-2): 1-48$

Kunst JR, Dovidio JF, Dotsch R (2018) White look-alikes: mainstream culture adoption makes immigrants 'look' phenotypically white. Personal Social Psychol Bull 44(2):265-282

Laclau E (2005a) On populist reason. Verso, London

Laclau E (2005b) Populism: what's in a Name? In: Panizza F (ed.) Populism and the mirror of democracy (Phronesis series). Verso Books, London, p 32-49

Laclau E (1996) Why do empty signifiers matter to politics? Emancip(S) $36: 46$

Lasch C (1991) The culture of narcissism: American life in an age of diminishing expectations. WW Norton \& Company, New York, NY

Lee JC and Quealy K (2017) The 389 people, places and things Donald Trump has insulted on Twitter., https://www.nytimes.com/interactive/2016/01/28/ upshot/donald-trump-twitter-insults.html, Accessed 2/8/2017

Lee, BX (2017). The dangerous case of Donald Trump: 27 psychiatrists and mental health experts assess a president. New York, Thomas Dunne Books

Lefort C (1986) The political forms of modern society: bureaucracy, democracy, totalitarianism. In: Thompson JB (ed). MIT Press

Lichtman A (2017) The case for impeachment. Harper Collins, New York, NY

Lisle-Williams M (1984) Beyond the market: the survival of family capitalism in the English merchant banks. Br J Sociol 35(2):241-271

Marx K (1981) Capital. Volume 3. Penguin, London

Marx K (1994) The eighteenth Brumaire of Louis Napoleon. International Publishers Comapny, New York, NY

McCarthy T (2017) Women are pissed: Trump protest turns to action. https:// www.theguardian.com/us-news/2017/nov/24/trump-women-femalecandidates-pennsylvania-the-promise, Accessed 28/11/2017

McDonnell D (2016) Populist leaders and coterie charisma. Political Stud 64 (3):719-733

Mertz C (2017) Distract, distort, isolate and the authoritarian style in US politics: an interview with Henry Giroux. http://www.truth-out.org/news/item/42198distract-distort-isolate-trump-and-the-authoritarian-style-in-us-politics. Accessed 30/11/2017

Moore MP (2003) Making sense of salmon: Synecdoche and irony in a natural resource crisis. West J Commun 67(1):74-96

Mouffe C (2009) Democracy in a multipolar world. Millennium 37(3):549-561

Mudde C, Kaltwasser CR (2013) Exclusionary vs. inclusionary populism: comparing contemporary Europe and Latin America. Gov Oppos 48(2):147-174

Ouellette L (2016) The Trump show. Telev New Media 17(7):647-650

Panizza F (ed.) (2005) Populism and the mirror of democracy. (Phronesis series). Verso Books, London, p 1-31

Porter D \& Prince D (2016) The Man who would be King. Bloodmoon Publishers Roediger DR (1999) The wages of whiteness: race and the making of the American working class. Verso, London

Root WA (2016) Angry white male: how the Donald Trump phenomenon is changing America and what we can all do to save the middle class. Skyhorse Publishing

Sartre J-P (1991) Critique of dialectical reason. Verso Books, London
Schreckinger B and Gold H (2017) Trump's fake war on the fake news. https:// www.politico.com/magazine/story/2017/04/23/trump-loves-media-reporterswhite-house-215043, Accessed 28/04/2017

Smith DE (1993) The standard North American family: SNAF as an ideological code. J Fam Issues 14(1):50-65

Shafer J (2015) Donald Trump Talks like a third grader, Politico Magazine, https:// www.politico.com/magazine/story/2015/08/donald-trump-talks-like-a-thirdgrader-121340, Accessed 16/11/ 2017

Streeck W (2017) Trump and the Trumpists Inference 3(1):1-11

Street J (2018) What is Donald Trump? Forms of 'celebrity' in celebrity politics. Polit Stud Rev 1-11, https://doi.org.ezproxy.aut.ac.nz/10.1177\% 2F1478929918772995

Thoemmes FJ, Conway LG (2007) Integrative complexity of 41 US presidents. Political Psychol 28(2):193-226

Thomas B (2016) The Trump factor: unlocking the secrets behind the Trump empire. Posthill Press

Thompson JB (1990) Ideology and modern culture. Stanford University Press, Stanford

Trump D (2015) Crippled America: how to make America great again. Threshold edition, New York, NY

Trump D (1987) The art of the deal. Arrow Books, London

Turner S (2003) Charisma reconsidered. J Class Sociol 3(1):5-26

Wernick A (1991) Promotional culture. Sage, London

Whiticker A (2016) Trumped: the wonderful world and wisdom of Donald Trump. New Holland Publishers, London

Wolff M (2018) Fire and fury: inside the Trump White House. Little Brown, New York, NY

\section{Data availability}

All data generated or analysed during this study are included in this published article.

\section{Acknowledgements}

The author wishes to acknowledge the assistance of Andrea Sisk King in proofing the article.

\section{Additional information}

Competing interests: The author declares no competing interests.

Reprints and permission information is available online at http://www.nature.com/ reprints

Publisher's note: Springer Nature remains neutral with regard to jurisdictional claims in published maps and institutional affiliations.

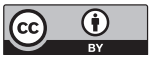

Open Access This article is licensed under a Creative Common Attribution 4.0 International License, which permits use, sharing, adaptation, distribution and reproduction in any medium or format, as long as you give appropriate credit to the original author(s) and the source, provide a link to the Creative Commons license, and indicate if changes were made. The images or other third party material in this article are included in the article's Creative Commons license, unles indicated otherwise in a credit line to the material. If material is not included in the article's Creative Commons license and your intended use is not permitted by statutory regulation or exceeds the permitted use, you will need to obtain permission directly from the copyright holder. To view a copy of this license, visit http://creativecommons.org/ licenses/by/4.0/.

(C) The Author(s) 2018 